\title{
Fungi Associated with the Spoilage of Post-harvest Tomato Fruits Sold in Major Markets in Awka, Nigeria
}

\author{
Onuorah Samuel ${ }^{*}$, Orji M.U. \\ Department of Applied Microbiology and Brewing, Nnamdi Azikiwe University, Nigeria
}

Copyright (C) 2015 by authors, all rights reserved. Authors agree that this article remains permanently open access under the terms of the Creative Commons Attribution License 4.0 International License

\begin{abstract}
Tomato contains large amount of water which makes it more susceptible to spoilage by fungi. These fungi that spoil tomatoes produce mycotoxins that are detrimental to human health. This study was therefore carried out to isolate, characterize and identify the fungi associated with the spoilage of tomato fruits sold in Okpuno, Amaudo, EkeAwka, Nodu and Amaikwo Markets in Awka, Nigeria. The average fungal counts ranged between $1.3 \times 10^{3}$ and $2.0 \times 10^{3}$ $\mathrm{cfu} / \mathrm{ml}$, while the fungal isolates were Aspergillus niger, Rhizopus stolonifer, Fusarium oxysporum, Saccharomyces cerevisiae, Alternaria alternata, Penicillium digitatum and Geotrichum candidum. The percentage occurrence of the isolates in the fruits from Eke Awka was the highest (32.73\%) while that of the fruits from Nodu market was the least $(12.73 \%)$. Aspergillus niger had the highest percentage occurrence $(47.27 \%)$ in the fruits studied, with Saccharomyces cerevisiae and Geotrichum candidum having the lowest percentage occurrence (3.64\%). Pathogenicity test result showed that Aspergillus niger also had the highest decay diameter of $30 \mathrm{~mm}$ in the healthy tomato fruits while Geotrichum candidum had the lowest decay diameter. Proper handling and adequate storage facilities must therefore be employed to prolong the shelf life of tomato fruits.
\end{abstract}

Keywords Fungi, Spoilage, Post-Harvest, Tomato Fruits, Major Markets

\section{Introduction}

Tomato is a widely consumed fruit eaten in both raw and processed forms [1]. It has the botanical name Lycopersicum Esculentum and belongs to the plant family solanaceae. It is rich in vitamins including vitamin $\mathrm{A}$ and vitamin $\mathrm{C}$, carbohydrates, proteins, fats, fibres and potassium [2]. It is rich in lycopene which has many beneficial health effects. It contains large amount of water which makes it more susceptible to spoilage by the action of microorganisms [3]. Tomato has a much lower sugar content than other fruits and is therefore not as sweet.

Tomatoes may be pear-shaped, elongated, flattened and heart shaped. They are edible, fleshy and reddish when ripe and vary in their acid composition, with white and yellow ones being less acidic. Tomatoes can be used as savoury or flavouring in soups and cooked foods or can be eaten as fruits. It is used in many dishes, salads, sauces and drinks and can also be dried and ground into pancakes [4].

The consumption of tomatoes throughout the world is believed to benefit the heart and other organs. The richest source of lycopene is tomato and tomato-based products [5]. Lycopene has been found to prevent prostate cancer, improve the skin's ability to protect itself against the harmful ultra violet rays, decrease the risk of breast, lung, stomach, bladder, uterine, head and neck cancers, protect against neurodegenerative diseases, lower urinary tract infections and reduce the cardiovascular risk associated with type 2 diabetes [6-10]. Tomatoes have serious challenges to their existence. These include changes in climate conditions, pests, inadequate rainfall and microorganisms particularly fungi. One of the limiting factors that influence tomato economical value is its relatively short shelf life caused by pathogen attack.

Spoilage of tomatoes are those adverse changes in the quality of tomatoes that are brought about by the action of predominantly biological and physical factors. These may be changes in taste, smell, appearance or texture of the fruits. Ghosh [11] reported that fungi were the source of spoilage of most of the tomato samples accessed than bacteria. Fungi affecting tomatoes include Aspergillus phoenicis, Absidia spp, Trichoderma spp, Alternaria alternata, Fusarium oxysporum, Fusarium moniliformis, Aspergilli us niger, Mucor spp, Rhizopus stolonifer, Penicillium spp, Geotrichum spp and Phytophthora spp [12-19].

Fungal spoilage of tomatoes has been recognized as a source of potential health hazard to humans and animals due to the fact that they produce mycotoxins which are capable of causing mycotoxicoses in man following ingestion or inhalation [18]. The mycotoxins are not limited to their areas of infections. Since tomatoes contain large amount of fluid, 
these mycotoxins diffuse rapidly throughout them, contaminating all parts and making the fruits unfit for consumption. The importance of tomato in the food industry and its nutritional benefits cannot be overemphasized. Routine microbiological examination of tomatoes is very crucial as it contributes to a large extent to economic development.

Tomatoes are consumed either raw or cooked worldwide. Numerous reports on their spoilage organisms in the developed countries are available but there is dearth of information on the spoilage organisms of tomatoes in a developing city such as Awka, Nigeria. There is therefore a need to evaluate the fungi associated with their spoilage, hence in this work, the fungi associated with the spoilage of post-harvest tomatoes sold in major markets in Awka, Nigeria were isolated, characterized and identified.

\section{Materials and Methods}

\subsection{Samples Collection}

Thirty tomato samples were purchased from Okpuno, Amaudo, Eke Awka, Nodu and Amaikwo markets in Awka, Anambra State, Nigeria. They were transported to the microbiology laboratory of Nnamdi Azikiwe University Awka in sterile polythene bags for fungal isolation. The samples were left for one week for spoilage to occur. The thirty spoilt tomatoes were used for the study.

\subsection{Materials Sterilization}

All the glass wares were properly washed, dried and sterilized in the oven at $160^{\circ} \mathrm{C}$ for one hour. The entire working surfaces were also disinfected with ethanol to reduce contaminants.

\subsection{Samples Processing}

One gram of each of the spoilt tomatoes was carefully cut with the aid of a sterile scalpel and enriched in sterile sabouraud dextrose broth for twenty four hours. Ten fold serial dilutions of the samples were thereafter carried out.

\subsection{Isolation of Fungi}

The pour plate method was used. One milliliter of the serially-diluted sample $\left(10^{3}\right)$ was dispensed into a conical flask containing sterile sabouraud dextrose agar (SDA) and two percent chloramphenicol to inhibit bacterial growth. The contents were properly mixed and dispensed aseptically into sterile petri-dishes. Incubation was carried out in an inverted position at $28^{\circ} \mathrm{C}$ for five days. The colonies that developed were counted and subcultured repeatedly on sabouraud dextrose agar plates to obtain pure cultures. They were later stored on SDA slants for characterization and identification.

\subsection{Characterization and Identification of the Isolates}

The pure cultures of the moulds were identified on the basis of their colony growth pattern, conidial morphology and pigmentation using the slide culture technique and microscopic examination. The yeasts were characterized and identified using the Gram stain, Chlamydospores formation, Germ tube, sugar assimilation and motility tests. The identity of each fungus was confirmed with the aid of a mycological atlas.

\subsubsection{Slide Culture Technique}

A fragment of the aerial mycelia was picked with a sterile inoculating needle and inoculated on a slide containing prepared sabouraud dextrose agar. The slide was thereafter incubated at room temperature for twenty four hours after which it was examined under the microscope.

\subsubsection{Microscopic Examination}

Lactophenol cotton blue solution was used. A drop of the solution was placed on a clean grease-free slide. A fragment of the mould was emulsified in the solution after which the slide was covered with a cover slip, avoiding bubbles. The slide was thereafter viewed under the microscope.

\subsubsection{Gram Stain}

A smear of the test yeast cell was made on a slide and stained, using the Gram stain procedure. The slide was thereafter viewed under the microscope for the presence of gram positive yeast cells.

\subsubsection{Chlamydospore Formation Test}

The procedure employed by Menza et al [20] was used. The isolate was inoculated on corn meal agar containing tween 80 and incubated at $25^{\circ} \mathrm{C}$ for seventy two hours. The isolate was thereafter introduced on a slide and stained with lactophenol cotton blue solution. The slide was thereafter viewed under the microscope for chlamydospore formation.

\subsubsection{Germ Tube Test}

The procedure of Menza et al [20] was employed in the test. A colony of the test yeast was inoculated into human serum and incubated at $37^{\circ} \mathrm{C}$ for three hours. A drop of the incubated serum was placed on a microscope slide and covered with a coverslip. The slide was thereafter examined under the microscope for the presence of germ tube.

\subsubsection{Sugar Assimilation Test}

The test was performed using the procedure of Menza et al [20]. Carbohydrate-impregnanted filter paper discs were placed on carbohydrate-free yeast nitrogen base agar contained in petri-dishes and incubated at $30^{\circ} \mathrm{C}$ for eighteen hours Growth around the paper discs was thereafter observed. Growth in the medium indicated the ability of the isolate to assimilate a sugar. The sugars used were glucose, sucrose, lactose, raffinose and galactose. 


\subsubsection{Motility Test}

Hanging drop slides were used. Vaseline was spread with a sterile toothpick on the corners of a clean coverslip. A drop of the yeast suspension was aseptically placed on the centre of a coverslip using a sterile inoculating loop. The depression slide was lowered on the coverslip so that the drop protruded into the centre of the concavity of the slide. The hanging drop slide was turned over and placed on the stage of the microscope so that the drop was on the light hole. The drop was thereafter examined under the microscope.

\subsection{Pathogenicity Test of the Isolates}

The procedures of Chukwuka et al [21], Baiyewu et al [22] and Onuorah et al [23] were used. Fifteen healthy tomatoes were properly washed with tap water, rinsed with distilled water and surface-disinfected with ethanol. Sterile cork borers were used to bore holes in each of the tomato fruits. Each of the isolated fungi was thereafter inoculated into the fruits after which the cores of the fruits were replaced. Sterile petroleum jelly was used to seal the holes of the fruits to prevent contamination. Fifteen tomato fruits wounded with the cork borers but were not inoculated with the fungi served as controls.

The inoculated tomato fruits and the controls were placed in sterile polythene bags (one fruit per bag). Each of the fruits was moistened with wet balls of absorbent cotton wool to create a humid condition. The fruits were thereafter incubated at $28^{\circ} \mathrm{C}$ for five days and observed for spoilage. The fungi were re-isolated from the fruits and compared with the original isolates. The decay rate of each fungus in the healthy fruits was also determined by measuring its rot diameter after two weeks of its inoculation into the healthy tomato fruit.

\section{Results}

The average fungal counts of the spoilt tomato fruits are presented in Table 1. The fruits from Eke Awka market had the highest count of $2.0 \times 10^{3} \mathrm{cfu} / \mathrm{ml}$ while those from Nodu market had the lowest count of $1.3 \times 10^{3} \mathrm{cfu} / \mathrm{ml}$.

Table 1. Average fungal counts of the spoilt tomato fruits

\begin{tabular}{|c|c|}
\hline Market & Average fungal counts $\left(\mathrm{x} 10^{3} \mathrm{cfu} / \mathrm{ml}\right)$ \\
\hline Okpuno & 1.6 \\
\hline Amaudo & 1.7 \\
\hline Eke-Awka & 2.0 \\
\hline Nodu & 1.3 \\
\hline Amaikwo & 1.8 \\
\hline
\end{tabular}

The fungal isolates from the spoilt tomato fruits are shown in Table 2. They were Aspergillus niger, Rhizopus stolonifer, Fusarium oxysporum, Saccharomyces cerevisiae, Alternaria alternata, Penicillium digitatum and Geotrichum candidum.

Table 2. Fungal isolates from the spoilt tomato fruits

\begin{tabular}{|c|l|}
\hline Market & \multicolumn{1}{c|}{ Fungal isolates } \\
\hline Okpuno & Aspergillus niger and Rhizopus stolonifer \\
\hline Amaudo & Fusarium oxysporum, Rhizopus stolonifer and Aspergillus niger \\
\hline Eke Awka & $\begin{array}{l}\text { Fusarium oxysporum, Saccharomyces cerevisiae, Alternaria alternata, Penicillum digitatum and } \\
\text { Aspergillius niger }\end{array}$ \\
\hline Nodu & Geotrichum candidum and Aspergillus niger \\
\hline Amaikwo & Aspergillus niger, Rhizopus stolonifer and Alternaria alternata \\
\hline
\end{tabular}

The occurrence of the fungi in relation to the markets is shown in Table 3. The fungi occurred most in the samples from Eke Awka market (32.73\%) while they had the lowest occurrence in the fruits from Nodu market (12.73\%).

Table 3. Percentage of the fungi in relation to the markets

\begin{tabular}{|c|c|c|c|c|c|c|c|c|}
\hline Markets & $\begin{array}{l}\text { Aspergillus } \\
\text { niger (n) }\end{array}$ & $\begin{array}{c}\text { Rhizopus } \\
\text { stolonifer } \\
\text { (n) }\end{array}$ & $\begin{array}{c}\text { Fusarium } \\
\text { oxysporum } \\
\text { (n) }\end{array}$ & $\begin{array}{c}\text { Saccharomyces } \\
\text { Cerevisiae (n) }\end{array}$ & $\begin{array}{c}\text { Alternaria } \\
\text { alternata } \\
\text { (n) }\end{array}$ & $\begin{array}{l}\text { Penicillum } \\
\text { digitatum } \\
\text { (n) }\end{array}$ & $\begin{array}{c}\text { Geotrichum } \\
\text { candidum } \\
\text { (n) }\end{array}$ & $\begin{array}{c}\% \\
\text { occurrence }\end{array}$ \\
\hline Amaudo & 4 & 3 & 3 & 0 & 0 & 0 & 0 & 18.18 \\
\hline Eke-Awka & 7 & 0 & 4 & 2 & 2 & 3 & 0 & 32.73 \\
\hline Amaikwo & 6 & 2 & 0 & 0 & 4 & 0 & 0 & 21.82 \\
\hline & & & & & & & & \\
\hline
\end{tabular}

$\mathrm{n}=$ number of isolates

The percentage occurrence of the fungi from the spoilt tomato fruits is presented in Table 4. Aspergillus niger occurred most frequently (47.27\%) while Saccharomyces cerevisiae and Geotrichum candidum had the lowest percentage occurrence (3.64\% each). 
Table 4. Percentage occurrence of the fungal isolates in the spoilt tomato fruits

\begin{tabular}{|c|c|c|}
\hline Fungi & No. of Isolates & \% Occurrence \\
\hline Aspergillus niger & 26 & 47.27 \\
\hline Rhizopus stolonifer & 9 & 16.36 \\
\hline Fusarium oxysporum & 7 & 12.73 \\
\hline $\begin{array}{c}\text { Saccharomyces } \\
\text { cerevisiae }\end{array}$ & 2 & 3.64 \\
\hline Alternaria alternata & 6 & 10.91 \\
\hline Penicillium digitatum & 3 & 5.45 \\
\hline Geotrichum candidum & 2 & 3.64 \\
\hline
\end{tabular}

The decay diameter of the fungi in the healthy tomato fruits is presented in Table 5. Aspergillus niger had the highest decay diameter of $30 \mathrm{~mm}$ while Geotrichum candidum had the least decay diameter of $10 \mathrm{~mm}$.

Table 5. Decay diameter of the fungi in the healthy tomato fruits

\begin{tabular}{|c|c|}
\hline Fungi & Decay diameter $(\mathrm{mm})$ \\
\hline Aspergillus niger & 30 \\
\hline Rhizopus stolonifer & 22 \\
\hline Fusarium oxysporum & 19 \\
\hline Saccharomyces cerevisiae & 11 \\
\hline Alternaria alternata & 16 \\
\hline Penicillium digitatum & 12 \\
\hline Geotrichum candidum & 10 \\
\hline
\end{tabular}

\section{Discussion}

The fungi associated with the spoilage of post-harvest tomato fruits sold in major markets in Awka, Nigeria were studied and the result revealed the presence of a teeming population of fungi. The average fungal counts ranged from $1.3 \times 10^{3}$ to $2.0 \times 10^{3} \mathrm{cfu} / \mathrm{ml}$. The fruits from Eke-Awka market had the highest count of $2.0 \times 10^{3} \mathrm{cfu} / \mathrm{ml}$ while those from Nodu market had the lowest count of $1.3 \times 10^{3} \mathrm{cfu} / \mathrm{ml}$ (Table 1).

The fungal isolates from the fruits were Aspergillus niger, Rhizopus stolonifer, Fusarium oxysporum, Saccharomyces cerevisiae, Alternaria alternata, Penicillium digitatum and Geotrichum candidum (Table 2). Ibrahim et al [15] isolated Aspergillus niger as one of the major fungi responsible for the production of volatile compounds in spoilt tomatoes. Baker [18] also isolated Aspergillus niger from rotten tomato fruits and reported that they are pathogenic on tomato fruits. Akinmusire [13] reported that Rhizopus spp were associated with the spoilage of tomatoes. Wogu and Ofuase [24] isolated Aspegillius spp, Penicillum spp, Fusarium spp and Saccharomyces spp from spoilt tomato fruits. Mbajiuka and Enya [25] also isolated Aspergillius spp, Penicillum spp and Saccharomyces cerevisiae from spoilt tomatoes while Fatih et al [19] reported the presence of Alternaria alternata and Fusarium oxysporum in the spoilt tomato fruits they studied. Ghosh [11] also isolated Fusarium oxysporum, Aspergillius niger and Rhizopus stolonifer from the spoilt tomato fruits studied.

The percentage occurrence of the fungi in relation to the markets showed that the fungi had the highest percentage occurrence of $32.73 \%$ in the samples from Eke Awka market while their percentage occurrence was lowest $(12.73 \%)$ in the fruits from Nodu market (Table 3). The detection of more fungi in the fruits from Eke-Awka market could be as a result of poor sanitation, overcrowding, poor storage and unhygienic practices by the fruits handlers.

Aspergillus niger had the highest percentage occurrence of $47.27 \%$ in the spoilt tomato fruits examined while Saccharomyces cerevisiae and Geotrichum candidum each had the lowest percentage occurrence of $3.64 \%$ in the fruits studied in (Table 4). The result agreed with the work of Akinmusire [13] and Ibrahim et al [15] They reported that Aspergillus niger had the highest rate of occurrence in the tomato fruits they studied and concluded that the fungus may be the major organism responsible for the spoilage of tomato fruits.

The result of the pathogenicity test showed that the fungi inoculated into the healthy tomato fruits had the same features as the ones re-isolated from them, indicating that the fungi were responsible for the spoilage of the tomato fruits. Aspergillus niger produced the highest rot in the tomato fruits, with a rot diameter of $30 \mathrm{~mm}$ while Geotrichum candidum produced the lowest rot diameter of $10 \mathrm{~mm}$ in the tomato fruits (Table 5).

Fungal spoilage of tomatoes is attributable to the high water content, environmental conditions, state of handling, state of storage facilities, the fungal load of the handlers and the quality of the tomatoes. These fungi isolated in this study are sources of potent mycotoxins which are detrimental to health. Aspergillus niger is a source of Ochratoxin which is considered to be a potent Carcinogen, therefore spoilt tomatoes must not be consumed but disposed off, since such consumption could be detrimental to health. Farmers and marketers of the produce are also advised to take appropriate precautions during the harvesting, transportation, storage and sale of tomatoes to reduce the risk of these toxins and other metabolites that are deleterious to health.

\section{Conclusions}

Tomato fruits have high dietary and nutritional qualities. Their spoilage by fungi results in loss of economic resources as well as food poisoning. The fruits are usually transported from areas of production to areas of consumption in locally woven baskets and sacks under conditions that encourage the growth of fungi. Good quality control measures must therefore be employed by the farmers, marketers and consumers during the harvesting, transportation, handling and processing of the fruits. Frequent inspection of the fruits for sale by food inspectors is also recommended. These will 
go a long way in preventing the consumption of contaminated tomato fruits thereby reducing the health hazards posed by the mycotoxins produced by these fungi isolated in this study.

\section{REFERENCES}

[1] K.M. Moneruzzaman, A.B.M.S. Hossain, W. Sani, M. Saiffudin. Effect of stages of maturity and ripening conditions on the biochemical characteristics of tomato. Americal Journal of Biochemistry and Biotechnology, Vol. 4, No.4, 336-344, 2008. DOI:10.3844/ajbbsp.2008.336.344.

[2] J. Talvas, C. Caris-veyrat, L. Guy, M. Rambeau, B. Lyan, R. Minet-Quinard, J.A. Lobaccaro M. Vasson, S. George, A. Mazur, E. Rock. Differential effects of lycopene consumed in tomato paste and lycopene in the form of a purified extract on target genes of cancer prostatic cells. American Journal of Clinical Nutrition, Vol.91, No. 6, 1716-1724, 2010. doi: 10.8945/ajen.2009.28666.

[3] Y. Bai, P. Lindhout. Domestication and breeding of tomatoes: What have we gained and what can we gain in the future? Annals of Botany, Vol.100, No.5, 1085-1094, 2006. doi: 10.1093/aob/mcm150.

[4] B.J.O. Effiuwevwere. Microbial spoilage agents of tropical and assorted fruits and vegetables. Paragraphics publishing company, Port Harcourt, Nigeria. PP 1-39,2000.

[5] M. Evangelia, G. Stefania, S. Gizzi, R. Ruggero, R. Stefano. Passion flower fruit- A new source of lycopene? Journal of Medicine and Food, Vol 81, No.1, 104-106, 2005. DOI: 10.1089/jmf.2005.8.104.

[6] F. Shidfar, N. Froghifar, M.R. Vafa, A. Rajab, S. Hosseini, S. Shidfar, M. Gohari. The effects of tomato consumption on serum glucose, apolipoprotein B, apolipoprotein A-I, homocysteine and blood pressure in type 2 diabetic patients. International Journal of Food Science and Nutrition, Vol.62, No.3, 289-294, 2010. Doi:10.3109/096374866.2010.529072.

[7] P. Zdenka, S. Peter, D. Hana, H. Milan. Antimutagenic effects of Lycopene and Tomato Puree. Journal of Medicine and Food, Vol.13, No.6, 1443-1450, 2010. DOI: 10.1089/jmf.2009.0277.

[8] R.G. Borguini, E.A.F.D.S. Torres Tomatoes and tomato products as dietary sources of antioxidants. Food Review International, Vol. 25, No.4, 313-325, 2009. http://www.Sciepub.com/reference/63681.

[9] C. Zhang, C. Suzanne, Ho, Y. Chen, J. Fu, S. Cheng, F. Lin. Greater vegetable and fruit intake is associated with a lower risk of breast cancer among Chinese Women. International Journal of Cancer, Vol.125, No.1, 181-188, 2009. DOI:10.1002/ijc.24358.

[10] N.D. Freedman, Y. Park, A.F. Subar, A.R. Hollenbeck, M.F. Leitzmann, A. Schatzkin, C.C. Abnet. Fruit and vegetable intake and head and neck Cancer risk in a large United States Prospective Cohort Study. International Journal of Cancer, Vol. 122 No.10, 2330-2336, 2008. DOI:10.1002/ijc.23319.

[11] A. Ghosh. Identification of microorganisms responsible for spoilage of tomato (lycopersicum esculentum) fruit. Journal of Phytology, Vol. 1, No.6, 414-416, 2009. http://www.scopemed.org/?mno=192987.

[12] E. Etebu, A.B. Nwauzoma, D.D.S. Bawo. Postharvest spoilage of tomato (lycopersicum esculentum Mill) and control strategies in Nigeria. Journal of Biology, Agriculture and Healthcare, Vol. 3, No.10, 51-63, 2013. http://www.iiste.org.

[13] O.O. Akinmusire. Fungi species associated with the spoilage of some edible fruits in Maiduguri, North eastern Nigeria. Advances in Environmental Biology, Vol.5, No.1 157-161, 2011. http://www.aensiweb. Com/old/aeb/2011/157-161.

[14] A.R. AL-Hindi, A.R. AL-Najada, S.A. Mohammed. Isolation and identification of some fruit spoilage fungi: Screening of plant cell wall degrading enzymes. African Journal of Microbiology Research, Vol. 5, No. 4, 443-448, 2011. DOI: 10.5897/AJMR 10.896.

[15] A.D. Ibrahim, K. Musa, A. Sani, A.A. Aliero, B.S. Yusuf. Microorganisms associated with the production of volatile compounds in spoilt tomatoes. Research in Biotechnology, Vol.2, No.2, 82-89, 2011.

http://www.unilorin.edu.ng/publications/sania/28.pdf

[16] A. O. Akintobi, I.O. Okonko, S.O. Agunbiade, O.R. Akano. O. Onianwa. Isolation and identification of fungi associated with the spoilage of some selected fruits in Ibadan South western Nigeria. Academia Arena, Vol.3, No. 11, 1- 10, 2011. http://www.sciencepub.net.

[17] A.H. Wani. An overview of the fungal rot of tomato. Mycopathology, Vol. 9, No.1, 1-5, 2011. Pu. edu. $\mathrm{Pk} / .$. /8-FINAL Review AH WANI 17-5-2012-vol 9 (1) 2011.pdf.

[18] S. Baker. Aspergillus niger genomics: past, present and into the future. Medical Mycology, Vol. 44, No.1, S17-21, 2006.DOI: $10.1080 / 13693780600921037$.

[19] K. Fatih, A.U. Tamer, M. Oskay. Determination of fungi associated with tomatoes (lycopersicum esculentum M.) and tomato pastes. Plant Pathology Journal, Vol.4, No.4, 146-149, 2005. DOI:10.3923/PPi. 2005.146.149.

[20] N. Menza, W. Wanyoike, W.M. Muturi. Prevalence of vaginal candidiasis and determination of the occurrence of Candia Species in Pregnant Women attending the ante-natal Clinic of Thika district hospital, Kenya. Open Journal of Medical Microbiology, Vol. 3, No. 4, 1-9, 2013. DOI: 10.4236/ojmm.2013.34040.

[21] K.S. Chukwuka, I.O. Okonko, A.A. Adekunle. Microbial Ecology of organisms causing pawpaw (Carica papaya L.) fruit decay in Oyo State, Nigeria. American-Eurasian Journal of Toxicological Science, Vol.2, No.1, 43-50, 2010. http://www/idosi.org/aejts/aejts 2 (1) 10.htm.

[22] R.A. Baiyewu, N. A. Amusa, O.A. Ayoola, O.O. Babalola. Survey of the Post-harvest diseases and aflatoxin contamination of marketed pawpaw fruit (Carica papaya L.) in south western Nigeria. African Journal of Agricultural Research, Vol.2, No.4, 178-181, 2007. http://www/.academic-journals.org/AJAR.

[23] S. Onuorah, I. Obika, U. Okafor. Filamentous fungi associated with the spoilage of post-harvest sweet orange fruits (citrus sinensis) sold in Awka Major Markets, Nigeria. Bioengineering and Bioscience, Vol. 3, No.3, 44-49, 2015. DOI:10.13189/bb.2015.030303. 
[24] M.D. Wogu, O. Ofuase . Microorganisms responsible for the spoilage of tomato fruits, lycopersicum esculentum, sold in markets in Benin City, Southern Nigeria. Scholar's Academic Journal of Bioscience, Vol. 2, No.7, 459-466, 2014. http://Saspublisher.com/sajb-27.
[25] C. Mbajiuka, E. Enya. Isolation of microorganisms associated with the deterioration of tomato, (lycopersicum esculentum) and pawpaw (Carica papaya L.) fruits. International Journal of Current Microbiology and Applied Sciences, Vol. 3, No. 5, 501-512, 2014. http://www.ijomas.com/vol-3-5/S. Mbajiuka, et al pdf. 